\title{
A wild Borneo orangutan carries large numbers of branches on the neck for feeding and nest building in the Danum Valley Conservation Area
}

\author{
Noko Kuze ${ }^{1}$, Hiroto Kawabata ${ }^{2}$, Saika Yamazaki ${ }^{3}$, \\ Tomoko Kanamori ${ }^{1}$, Titol Peter Malim ${ }^{4}$, Henry Bernard ${ }^{5}$ \\ 1) Wildlife Research Center, Kyoto University \\ 2) Independent writer/novelist; hirotok@fine.ocn.ne.jp \\ 3) United Graduate School of Agricultural Science, Tokyo University of Agriculture and \\ Technology \\ 4) Sabah Wildlife Department \\ 5) Institute for Tropical Biology and Conservation, Universit Malaysia Sabah
}

\section{INTRODUCTION}

Orangutans regularly build nests (Prasetyo et al., 2009) like other great apes (Fruth \& Hohmann, 1996). Nests are mainly constructed to provide a place for resting and protection from potential risks such as predation, heat loss, and parasites carried by insects like mosquitoes (McGrew, 2004). Immature orangutans acquire sufficient nestbuilding skills before separating from the mother (van Noordwijk et al., 2009). As the body size, cognition, and safety requirements continue to develop following infancy, the nest-building skills probably continue to be refined into adulthood (for more details, see Russon et al., 2007). Juvenile and adolescent orangutans are believed to acquire nesting skills through horizontal and/or modes of social transmission (Russon et al., 2007). Thus, nesting behaviour is generally reported as a cultural variants in orangutans, with 9 of the 35 cultural behavior variants showing nesting behaviour (van Schaik, 2009). Leaf-carrying behaviour, which is defined as the collection of nest materials before reaching the nest site (rather than afterwards), is a newly identified variant of orangutan nest-building behaviour (Russon et al., 2007; van Schaik et al., 2009). For example, Russon and colleagues (2007) showed the acquisition processes of leaf-carrying behaviour at some rehabilitation/re-introduction sites. However, literature reporting the occurrence of nest building and branch (or leaf) carrying behaviour in the wild remains scarce (Russon et al., 2007), although studies do exist on nest-site selection (i.e. preferred sites) and preference of species of nesting-tree (Sugardjito, 1983; Ancrenaz et al., 2004; Prasetyo et al., 2009). This report describes the direct observation of a single adult female orangutan in the wild that carried large numbers of fruit-laden branches for both feeding and nesting.

\section{METHODS}

The study area was located in the Danum Valley 
Conservation Area (DVCA; $438 \mathrm{~km}^{2}$ ), East Borneo, Sabah, Malaysia. The DVCA is a Class I Protection Forest Reserve that was established by the Sabah State Government in 1996, and is managed by the Sabah Foundation (Yayasan Sabah Group) for conservation, research, education, and tourism. The study was initiated in March 2005, and conducted in a primary forest (lowland dipterocarp forest) of approximately $2 \mathrm{~km}^{2}$, which was situated along the Danum River, a tributary of the Segama River (510101700N, 11714405000E, 231-384 m a.s.1.) (Kanamori et al., 2010). Between 2005 and 2007, the mean, maximum, and minimum temperature of this region was $27.1,31.7$, and $22.6{ }^{\circ} \mathrm{C}$, respectively. The annual rainfall in this area ranged from 2,350 $\mathrm{mm}$ to $3,083 \mathrm{~mm}$ (Kanamori et al., 2010; Data source: The Royal Society Southeast Asia Rain Forest Research Program, unpublished).

We observed 44 identified orangutan individuals between March 2005 and December 2010. Of the 44 animals, 24 were observed for a total period of more than six months, and were regarded as 'residents'. These, 24 individuals included six adult males (three flanged and three unflanged) and five adult females, one adolescent male and two adolescent females, three juvenile males and two juvenile females, and five infants. These 24 residents were well habituated to observers. We followed all 24 resident orangutans from their morning nest sites to their nocturnal nest sites every day, or until they were lost from view. We recorded their daily activities (i.e. feeding, resting, travelling, and others) and food consumed at every one min intervals by direct observation, following a standardised method of orangutan data collection (Morrogh-Bernard et al., 2002). A total of 524 observation days were assimilated for 37 individuals, from March 2005 to December 2010. However, the main subject of this study was a female orangutan named Sheena. Sheena was studied from 2005 onwards, with her nesting behaviour being observed on 12 days in total from March 2005 to December 2008. Within the same period, the average frequency of observed nesting behaviour by residents (14 of the resident orangutans) was 10.6 days (range, 1-21 days). In 2005, Sheena's age was estimated at ca. 10 years old (adolescent female), as the orangutan was no longer dependent on the mother, but had a smaller body size than adults with infants. The orangutan became pregnant between May and July 2010, after infertility for at least four years despite several copulation events.

\section{OBSERVATION}

This observation was made by two of the authors (NK and HK) and two assistants on 5 November 2010. At 15:20, one pregnant female named Sheena started feeding on the seeds of Lithocarpus sp. (Fagaceae). At 16:10, the orangutan started making a nest in the same tree (at a height of about $30 \mathrm{~m}$ ). After six min, it left the nest to again feed on the seeds. At 16:23, it placed more than five fork branches across its neck (Fig. 1, Electronic Resource 1), and then returned to the nest. The length of branches was more than $1 \mathrm{~m}$, and each branch had plenty of seeds. This tree was located at the foot of a hill; the authors and an assistant climbed the hill to observe the nest from the same height, while the other assistant continued the observation from under the tree. The observations at the nest height were initiated at 16:29, at a distance of about $30 \mathrm{~m}$ from the tree.

At 16:29, Sheena sat in the nest, and fed on the seeds of the collected branches of Lithocarpus sp. (Fig. 2, Electronic Resource 2). At 16:45, the orangutan removed all the branches from its back and held them with both hands. Then, it placed the branches on the nest as a lining. At 16:48, the 


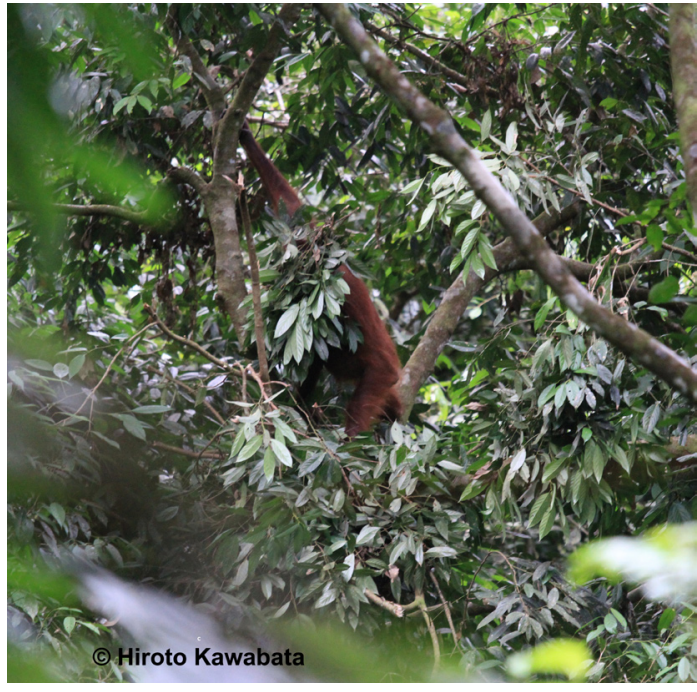

Fig. 1. Sheena carried branches on its neck.

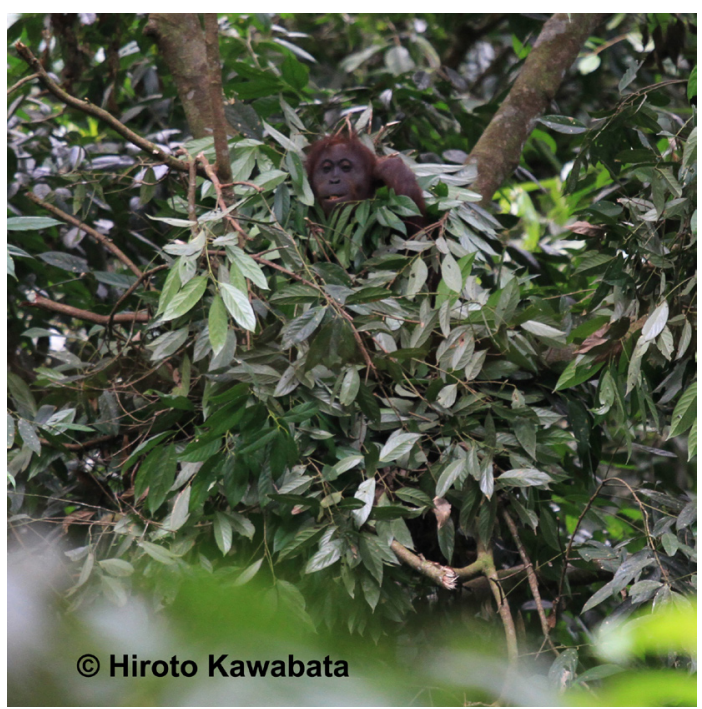

Fig. 2. Sheena fed on the seeds of Lithocarpus sp. on the nest.

orangutan lied down on the nest. At 16:49, it left the nest again, and ate the same seeds at a location $10 \mathrm{~m}$ beneath the nest. Following this, it again collected at least five forked branches and placed them on its neck. At 16:54, it returned to the nest, and fed on the seeds of the branches on its neck
(Electronic Resource 3). At 17:06, it removed the branches from around its neck, and placed them on the nest as lining (Electronic Resource 3). At 17:07, it lied down in the nest (Electronic Resource 3). Until 17:12, it rested in the nest, at which point the authors and assistants stopped the observations for the day.

\section{DISCUSSION}

The behaviour observed in this study has five distinctive characteristics: (1) carrying branches for nesting, (2) carrying branches for feeding, (3) carrying (forked) branches on the neck, (4) carrying branches of the same tree, and (5) carrying large numbers of branches at once. Most of these characteristics have been separately reported in the wild and rehabilitated orangutans, but not grouped together. Wild orangutans customarily carry one or two branches containing fruits for short distances (i.e. next to the previous feeding tree) or sometimes up to $150 \mathrm{~m}$ from the parent tree (Rijksen, 1978). Similarly, collecting and carrying some branches for nesting material after reaching the nesting site has also been observed in the wild (MacKinnon, 1974; Prasetyo et al., 2009). MacKinnon (1974) reported that orangutans carry the branches for nesting by holding them between their teeth, in a foot, under one arm, or between the chin and shoulder. Leaf carrying (collection of branches before reaching the nest site) is considered a cultural behaviour, and has been recorded in several populations: in one wild population (Tuanan, Indonesia) and in six rehabilitated populations (Russon et al., 2007; van Schaik et al., 2009). In Tuanan orangutans collect the branches of special tree species for building nests. These trees are almost exclusively Campnosperma sp., which, in fact, have mosquito repellent properties (van Schaik et al., 2009). It has not been confirmed whether Lithocarpus sp. also has mosquito repellent 
properties. However, this tree species may be primarily selected for feeding, rather than for antimosquito effects or other functions. MacKinnon (1974) also reported observations of orangutans feeding on leaves, shoots, or fruits while sitting on their nests. At our study site, some individuals were observed to occasionally carry one forked branch on their neck for feeding. To summarise, most characteristics of this observed behaviour (1-4) have been previously reported, i.e. orangutans carrying a few branches, occasionally placing the branches on the neck, as well as for feeding and nest building (Rijksen, 1978; MacKinnon, 1974; Prasetyo et al., 2009). However, characteristic (5), i.e. carrying large numbers of branches at once, has not been previously reported.

This behaviour is probably a cultural behaviour that has recently spread across Danum Valley, rather than an innovative behaviour by Sheena. Similar behaviour has also been observed in the same conservation area. Specifically, prior to 2009, Cede Prudente, a Malaysian animal photographer, shot a video in which a flanged male placed large numbers of branches on his neck for nest building in the vicinity of the Danum Valley Field Center (YouTube: http://www.youtube.com/ watch? $\mathrm{v}=3 \mathrm{eVYCEeZBAo)}$. This site was located $11 \mathrm{~km}$ from our study site. Both orangutans (Sheena and the flanged male) belong to the same population within the conservation area. It is possible that several individuals living inside the conservation area share this behavioural pattern. Prior to November 2010, this behaviour was not displayed by the orangutans in our study site, neither by Sheena nor by the other individuals. However, our study site did not cover the entire home range of Sheena. Therefore, it is possible that the orangutan observed another individual, living outside our study area, carrying several branches on the neck for nest building and/or feeding.
It is often discussed as to whether a newly observed variant behaviour in primates is acquired by social transmission (van Schaik \& Pradhan, 2003) or by individual learning (Galef, 1992). There is no evidence that Sheena acquired this behaviour by social transmission. However, Sheena was observed to share a nest made by a resident unflanged male in 2006, whereas the other adult residents were never observed to share a single nest with the other adults (except one pair of adolescent male - adolescent female). Therefore, it is possible that Sheena had the opportunity to observe this behaviour when it was in close proximity with other individuals.

\section{ACKNOWLEDGEMENTS}

We thank the Economic Planning Unit of the Malaysia Federal Government, the Economic Planing Unit of the Sabah State Government, Danum Valley Management Committee, and Sabah Wildlife Department for permission to conduct this study in Sabah. We are grateful to the supporters of our research, including Dr. Waidi Sinun, Mr. Jimmy Omar, Mr. Jikos Gidiman, Mrs. Rose John Kidi of Yayasan Sabah, Mr. George Hong of Borneo Nature Tours, Dr. Glen Reynolds of Danum Valley Field Centre, the staff at Borneo Rainforest Lodge, Dr. Gen'ichi Idani and Dr. Shiro Kohshima from the Wildlife Research Center of Kyoto University, Dr. Tetsuro Matsuzawa from the Primate Research Institute, Dr. Carel P. van Schaik from the University of Zurich, Dr. Marc Ancrenaz from HUTAN, and Mr. Cede Prudente. We would also like to thank our research assistants for their help in the field. This study was partly supported by a grant from the JSPS-HOPE (Primate Origins of Human Evolution) Project, AS-HOPE (the Advanced Studies on the Evolutionary Origins of Human Nature), Global Environment Research Fund (F-061, D-1007), 21st century COE programs 
(Grant No. A06 and No, A14), Graduate School of Science, Kyoto University, Graduate School of Science, Tokyo Institute of Technology (Grant No. R12 and A10), the Japanese Association of Zoos and Aquariums (JAZA), and JSPS Research Fellowships for Young Scientists and Grant-in-Aid for Young Scientists (B).

\section{REFERENCES}

Ancrenaz M, Calaque R, Lackman-Ancrenaz I 2004: Orangutan nesting behavior in disturbed forest of Sabah, Malaysia: Implications for nest census. Int $\mathrm{J}$ Primatol 25:983-1000.

Fruth B, Hohmann G 1996: Nest building behavior in the great apes: the great leap forward? In McGrew WC, Marchant LF, Nishida T (eds): Great ape societies, Cambridge University Press, Cambridge, pp. 225-240.

Galef B 1992: The question of animal culture. Hum Nat 3:157-178.

Kanamori T, Kuze N, Bernard H, Malim TP, Kohshima S 2010: Feeding ecology of Bornean orangutans (Pongo pygmaeus morio) in Danum Valley, Sabah, Malaysia: a 3 -year record including two mast fruitings. Am J Primatol 72:820-840.

MacKinnon J 1974: The behaviour and ecology of wild orangutans (Pongo Pygmaeus). Anim Behav 22:3-74.

McGrew WC 2004: The cultured chimpanzees. Cambridge University Press, Cambridge, UK.

Morrogh-Bernard HC, Husson S, McLardy C 2002: Orang-utan data collection standardization. LSB Leakey Foundation Orang-utan Culture Workshop, San Anselmo, California (http://www.aim.uzh.ch/ orangutannetwork/FieldGuidelines.html).

Prasetyo D, Ancrenaz M, Morrogh-Bernard HC, Utami Atmoko SS, Wich SA, van Schaik CP 2009: Nest building in orangutans. In Wich SA, Utami SS, Mitra Setia T, van Schaik CP (eds): Orangutans: Geographical Variation in Behavioral Ecology, Oxford University Press, Oxford, pp. 269-277.

Rijksen HD 1978: A Field Study on Sumatran Orang utans (Pongo pygmaeus abelli, Lesson 1827). Ecology, behavior, and conservation, H. Veenman and Zonen, Wageningen, The Netherlands.

Russon A, Handayani D, Kuncoro P, Ferisa A 2007: Orangutan leaf-carrying for nest-building: unraveling cultural processes. Anim Cogn 10:189-202.

Sugardjito J 1983: Selecting nest-sites of Sumatran orang- utans, Pongo pygmaeus abelii in the Gunung Leuser National Park, Indonesia. Primates 24:467-474.

van Noordwijk MA, Sauren SEB, Nuzuar, Abulani A, Morrogh-Bernard HC, Utami Atmoko SS, van Schaik CP 2009: Development of independence - Sumataran and Bornean orangutans compared. In Wich SA, Utami SS, Mitra Setia T, van Schaik CP (eds): Orangutans: Geographical Variation in Behavioral Ecology, Oxford University Press, Oxford, pp. 189-203.

van Schaik CP, Pradhan GR 2003: A model for tool-use traditions in primates: implications for the coevolution of culture and cognition. J Hum Evol 44:645-664.

van Schaik CP, Ancrenaz M, Djojoasmoro R, Knott CD, Morrogh-Bernard HC, Nuzuar, Odom K, Utami Atmoko SS, van Noordwijk MA 2009: Orangutan cultures revisited. In Wich SA, Utami SS, Mitra Setia T, van Schaik CP (eds): Orangutans: Geographical Variation in Behavioral Ecology, Oxford University Press, Oxford, pp. 299-309. 
(要約)

\title{
ダナムバレー森林保護区の野生ボルネオ・オランウータンが採食と 巣作りの為に大量の枝を肩にのせて運搬した事例の報告
}

\author{
久世濃子 ${ }^{1}$, 川端裕人 ${ }^{2}$, 山崎彩夏 $^{3}$, 金森朝子 ${ }^{1}$,

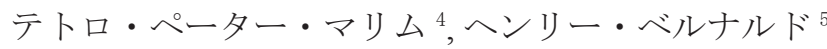

1）京都大学野生動物研究センター

2) 作家

3）東京農工大学連合農学研究科

4) Sabah Wildlife Department

5) Institute for Tropical Biology and Conservation, Universit Malaysia Sabah

オランウータンは他の大型類人猿と同様に, 毎日新しい巣を作る。巣は快適な休息をもたらし, 潜 在的な危険（捕食, 体温の低下, 寄生虫などの病原体）を防ぐ一方, 巣作り行動は, 認知科学の面から も興味深い行動である。野生オランウータンが巣を作る樹種や場所の選好性に関する研究はあるもの の, 巣作り行動の詳細に関する研究は少ない。本論文では 1 頭の野生のオトナ雌が, 採食と巣作りの為 に大量の枝を運搬した事例を報告する。2010 年 11 月, シーナという一頭のオトナ雌（推定 15 歳）が ブナ科の Lithocarpus 属の一種を採食していた。夕方, シーナは同じ木に巣を作った後, 二股にわかれ た枝（大量の果実と葉がついていた）を 5 本以上，肩にかけて巣に戻った。枝についていた Lithocarpus の種子を採食した後, シーナは残りの枝を巣材として使った。シーナは同じ行動 - 大量の枝を運び, 採 食した後, 巣材に使う - をもう 1 回繰り返し, 巣の中で就寝した。これらの行動は $30 \mathrm{~m}$ ほど離れた斜 面で観察し, 高品質の写真とビデオ映像を撮影した (電子資料 1 として公開)。オランウータンが 1 〜 2 本の枝を巣作りや採食の為に運搬する事例は, 本調查地でも他の調查地でも観察されている。しかし このように大量の枝を巣作りと採食の為に運搬するという行動は, 他の調查地からは今まで報告されて いない。一方, 本調査地から約 $11 \mathrm{~km}$ 離れた場所で, オトナ雄の同じような行動（大量の枝を肩にかけ て運び, 巣材として使う）が 2009 年より以前に観察されている。以上より, 今回観察された行動は, シー ナが新しく始めた行動というより，他個体から伝搬した行動だと考えられる。

Key words: culture, bed, great ape, orang-utan, leaf-carrying

Noko Kuze

Wildlife Research Center of Kyoto University

3F, 2-24 Tanaka-Sekiden-cho, Sakyo, Kyoto 606-8203, Japan

e-mail: nouko@mva.biglobe.ne.jp

久世濃子 京都大学野生動物研究センター

干 606-8203 京都市左京区田中関田町 2-24 京大関田南研究棟 